\title{
The role of Micro-CT in imaging breast cancer specimens
}

Cite this article as: Daniel DiCorpo, Ankur Tiwari, Rong Tang, Molly Griffin, Owen Aftreth, Pinky Bautista, Kevin Hughes, Neil Gershenfeld and James Michaelson, The role of Micro-CT in imaging breast cancer specimens, Breast Cancer Research and Treatment https://doi.org/10.1007/s10549-020-05547-z

This Author Accepted Manuscript is a PDF file of an unedited peer-reviewed manuscript that has been accepted for publication but has not been copyedited or corrected. The official version of record that is published in the journal is kept up to date and so may therefore differ from this version.

Terms of use and reuse: academic research for non-commercial purposes, see here for full terms. https://www.springer.com/aam-terms-v1 


\title{
The Role of Micro-CT in Imaging Breast Cancer Specimens
}

Daniel DiCorpo ${ }^{1}$, Ankur Tiwari ${ }^{1,2}$, Rong Tang ${ }^{2}$,

Molly Griffin ${ }^{1}$, Owen Aftreth ${ }^{5}$, Pinky Bautista ${ }^{1}$, Kevin Hughes ${ }^{2}$, Neil Gershenfeld ${ }^{6}$, James Michaelson ${ }^{1,2,3,4}$

\author{
${ }^{1}$ Laboratory for Quantitative Medicine \\ ${ }^{2}$ Division of Surgical Oncology \\ ${ }^{3}$ Department of Pathology \\ Massachusetts General Hospital \\ ${ }^{4}$ Department of Pathology \\ Harvard Medical School \\ ${ }^{5}$ Department of Urology \\ Kaiser Permanente \\ Los Angeles Medical Center, Los Angeles, CA \\ ${ }^{6}$ MIT Center for Bits and Atoms \\ Room E15-401 \\ 20 Ames Street \\ Cambridge, MA 02139 \\ 12 Sheeps Crossing Lane \\ Woods Hole MA 02543, USA \\ JamesMichaelsonPhD@gmail.com \\ 6175010590 \\ KEYWORDS \\ Breast Cancer; Margin; Surgery; Pathology
}

\section{ABSTRACT}

Purpose: The goal of breast cancer surgery is to remove all of the cancer with a minimum of normal tissue, but absence of full 3-dimensional information on the specimen makes this difficult to achieve.

Method: Micro-CT is a high resolution, X-ray, 3D imaging method, widely used in industry but rarely in medicine.

Results: We imaged and analyzed 173 partial mastectomies (129 ductal carcinomas, 14 lobular carcinomas, 28 DCIS). Imaging was simple and rapid. The size and shape of the cancers seen on Micro-CT closely matched the size and shape of the cancers seen at specimen dissection. Micro-CT images of multicentric/multifocal cancers revealed multiple non-contiguous masses. Micro-CT revealed cancer touching the specimen edge for $93 \%$ of the 114 cases judged margin positive by the pathologist, and 28 of the cases not seen as margin positive on pathological analysis; cancer occupied $1.55 \%$ of surface area when both the pathologist and Micro-CT suggested cancer at the edge, but only $0.45 \%$ of surface area for the "Micro-CT-Only-Positive Cases". Thus, Micro-CT detects cancers that touch a very small region of the specimen surface, which is likely to be missed on sectioning.

Conclusions: Micro-CT provides full 3D images of breast cancer specimens, allowing one to identify, in minutes rather than hours, while the patient is in OR, margin positive cancers together with information on where the cancer touches the edge, in a fashion more accurate than possible from the histology slides alone.

\section{INTRODUCTION}

The goal of breast cancer surgery is to remove of all the cancer and a minimum of the normal tissue. ${ }^{1}$ Unnecessary removal of normal tissue is disfiguring, with no health benefit, while leaving cancer behind can result in additional surgery, radiation therapy, ${ }^{2}$ local recurrence, ${ }^{3-8}$ and risk of death by spread of cells from the residual mass. ${ }^{9,10}$ For many patients, examination of the microscope slides reveals cancer at the specimen edge ("margin positive"), suggesting cancer remaining behind. While the rate of positive margins has decreased since the consensus on margins published in 2013, re-excision remains a significant problem, and much thoughtful consideration has focused on how best to use such information to guide treatment, especially re-excision. ${ }^{11,12}$ Because a 5 -micron microscope section captures only $\sim 1 / 2000^{\text {th }}$ of a $1 \mathrm{cc}$ mass, many studies have considered alternative methods for examining cancer specimens, ${ }^{13-33}$ as well as alternative surgical procedures ${ }^{34-38}$ such as shaved margins. ${ }^{39,40}$ (For reviews and references, see $14-16$ and 41-46.)

Micro-Focus X-Ray Computed Tomography, or Micro-CT, is a 3D imaging method developed principally for industry and materials science, but little used in medicine. For a number of reasons, we have explored its use in assessment of surgical specimens, especially partial mastectomies: ${ }^{47-51}$ FIRST, decades of clinical breast imaging have shown that X-rays can reveal cancer; ${ }^{24,31-33}$ 
SECOND, Micro-CT visualizes the full 3D anatomy of each specimen; THIRD, Micro-CT scans are fairly rapid, requiring minutes rather than hours to carry out, without interfering with subsequent specimen processing; FOURTH, since most cells are 5- to 20microns in $s^{5} \mathrm{e}^{52}$, and commercially available desktop Micro-CT machines can image specimens in the tens of microns range, MicroCT has the capacity to provide high resolution 3D images almost to the scale of cells. Furthermore, as the theoretical limits of X-Ray imaging far exceed that of optical imaging, and as the technology of Micro-CT imaging has been continuously improving, ${ }^{53,54}$ it seems likely that cellular level resolution may soon be available. In our preliminary studies, we have found that Micro-CT can generate full $3 \mathrm{D}$ images of tissue specimens, which are informative and actionable. ${ }^{47-51,55}$ However, the relatively small numbers of partial mastectomy breast cancer specimens that have been examined motivated study of a larger number and more diverse variety of cases, whose margin status, tumor size, and shape, are assessed systematically, as we describe here.

\section{METHODS:}

\section{Micro-CT imaging of specimens.}

173 partial mastectomy specimens (TABLE 1) were examined in at least one Micro-CT machine: SkyScan1173, SkyScan1275, or NikonXTH225. All imaging was carried out at $60 \mathrm{kV}$, with an exposure time of about 8 to 10 minutes, depending on which Micro-CT machine was used. These parameters were identified by multiple studies of animal tissue, typically Prosciutto ham, which we found to be the ideal biological phantom with X-Ray absorption characteristics most like human breast. All work was carried out under IRB approved study \#P001572 (JM PI).

\section{Reconstruction of the Micro-CT images.}

Micro-CT captured large numbers of X-Ray projection images as the surgical specimen was slowly rotated. Software provided by the manufacturers generated 3-dimensional stacks of data-points, known as voxels (3D Pixels), each with an X-Ray absorption value. Equipment was typically configured for generating planes in a stack of 45 microns in thickness, yielding about 1100 slices for the specimen as a whole. Reconstruction and processing of images occurred after acquisition. SkyScan datasets were processed with their proprietary nRecon reconstruction software, and Nikon datasets with their proprietary CT-Pro 3D software. Final reconstructions were outputted as image stacks in DICOM and TIFF.

While the imaging scanning time, and specimen processing times, were relatively short (see RESULTS section), image analysis of each case took many hours, and was repeated by multiple workers (see RESULTS section). This reflects the research-oriented nature of the work described here and is probably not informative for what could be expected should Micro-CT be transformed into a clinical tool. Both the equipment we used, and the image analysis software required to manage this equipment, and analyze the images, were designed for use by engineers, and to be maximally adaptable, thus requiring a fairly high level of engineering and software expertise to manage. Our general impression is that the visual examination of the location of the cancer in the specimen would take only a few minutes, in a Micro-CT designed for hospital use, as can be seen by an examination of the video we have included with this communication, but this would remain to be tested rigorously in the future.

\section{Viewing the Micro-CT images.}

Most imaging of the partial mastectomies, including assessment of margin status, was carried out with the Bruker DataViewer image visualization tool, which presents trans-axial, coronal, and sagittal views in two dimensions, allowing for smooth scrolling and viewing the entire specimen at any angle. Three-dimensional content of the Micro-CT images was also made by Bruker image reconstruction software (See attached Video File).

\section{Extraction of pathology data}

One member (DD) extracted data from pathology reports as categorical qualities, compiled into an excel file. This content was isolated and only employed after the blind Micro-CT reads were completed.

For analysis of breadloaffed specimens, a board-certified breast pathologist (TG) identified areas where cancer was located by microscopic analysis of the slides and annotated on printed images.

\section{The dataset}

\section{$\underline{\text { RESULTS }}$}

Features of the 173 partial mastectomies examined are summarized in TABLE 1. Of these 173 cases, 28 (16\%) were DCIS and $145(84 \%)$ were invasive cancers. Of the 129 invasive carcinomas, 14 were lobular carcinomas (10\%), 129 were ductal carcinomas (90\%), $112(87 \%)$ of the invasive cancers were noted by the pathologist to contain DCIS, while 17 (13\%) contained no DCIS, $108(84 \%)$ were judged by the pathologist to have only a single focus of cancer, while $21(16 \%)$ were judged multifocal, 10 of which $(8 \%)$ were judged to have exactly 2 foci.

The pathologist judged 114 of the 173 partial mastectomy specimens to be margin positive (66\%, "ink on tumor") and 59 as margin negative (34\%). A very large fraction of breast cancer patients at our hospital are afforded shaved margins, and these shaved margins excise residual cancer in a large number of cases. Thus, a much larger number of patients were ultimately rendered margin negative by this additional removal of tissue than is indicated by the margin status of the partial mastectomy specimens themselves. This afforded the opportunity to capture Micro-CT images of an unusually large number of specimens in which the cancer was seen by the pathologist to touch the edge on at least one slide. 


\section{Acquiring a Micro-CT image is simple and rapid and can be carried out with the specimen in the container}

We did not systematically collect information on the workflow of these studies, carried out over a multiyear period, However, our retrospective, if imprecise, recollection of the time-course of the imaging is that the time it took to scan the specimen when it was placed in the Micro-CT machine was 8 to 10 minutes (determined by the technical requirement of which Micro-CT machine were using). The total time, starting from the collection of the specimen from the OR, carrying the specimen to the room where the Micro-CT machine was located, imaging the specimen in the machine, and then carrying the specimen to the pathology lab, was approximately 30 minutes. The Micro-CT machine was located in a room that could be reached in a several minute walk from both OR and the pathology lab. Each partial mastectomy specimen was imaged in the Micro-CT machine while still in the plastic container into which it had been placed by the surgeon, scanned, and then sent on to the pathology lab for processing, the container remaining unopened throughout. Analysis of the Micro-CT images was carried out later, although there is no reason why one couldn't examine them immediately. Indeed, our overall impression was that Micro-CT image collection and reading could readily be carried out in real time for practical use in clinical care, but this should be regarded as a working hypothesis

\section{Appearance of the Micro-CT images of the partial mastectomy specimens}

Micro-CT scans of all 173 partial mastectomy specimens, when viewed with the Bruker Data-Viewer image visualization tool, revealed an image of a light-colored mass, suggesting the cancer, surrounded by somewhat darker areas, apparently the normal tissue (FIGURE 1). Other objects that came with the specimen were also apparent, including the plastic bag into which the surgeon placed the specimen, the plastic jar in which the surgeon placed the bagged specimen, with the wall of the jar appearing as a circle surrounding the specimen, along with the Kopans loop and clips inserted earlier, appearing as bright white objects, often giving off distortions, but having little practical impact on the interpretation of the image (FIGURES 1-3 in reference 47). The resolution of the Micro-CT images was remarkable; for example, one could read the writing on the jar's label.

The108 monofocal/monocentric invasive ductal carcinomas (as defined by the pathologist) usually appeared as solid masses, with little voxel-to-voxel variation in gray values and no gray spaces or holes, forming satisfying compact masses without "tendrils" or "off-shoots". In the adjacent normal-appearing tissues, blood vessels were readily evident, and Cooper's ligaments could be seen as sheets, as expected.

The14 invasive lobular carcinomas usually appeared as very large regions They were even more uniform and strikingly dense than the ductal carcinomas.

The 28 DCIS specimens appeared wispier in texture than invasive cancers, giving cloud-like appearance of gray values varying from dense to less dense areas. These images gave the impression of cancerous tissue spread over a wider area often reaching out into off-shoots from the main mass.

The 21 multicentric/multifocal cancers (as defined by the pathologist at examination of the specimen and slides) usually give striking images of separate, clearly non-contiguous, masses of cancer.

Additional image realization was carried out with image analysis software, with which we created a variety of threedimensional image visualizations seen by manipulation with Bruker image reconstruction software image analysis software, which allows image rotation, slicing, and the introduction of various degrees of transparency, achieved by volume rendering with adjustment of opacity and maximum intensity projection imaging modified by the transfer function, making viewing through the 3D mass possible (See attached Video File, and images from videos can be seen in FIGURES 2-3).

\section{Relationship of the Micro-CT image to the cancer}

Each of the 173 partial mastectomy specimens yielded a compelling Micro-CT image suggestive of the cancer mass, which was confirmed by the following observations.

The size of the spot seen on the Micro-CT is very similar to the size of the cancer seen at the time of dissection of the gross specimen.

Comparison of the size of the mass on the Micro-CT to the size of the actual cancer measured by the technologist from the gross specimen with a ruler at the time of sample preparation revealed the correlation between the two modalities to be quite good (FIGURE 4, Pearson Correlation Coefficient $0.7932, \mathrm{p}<0.0001$ ). These size data were available for 80 patients with invasive cancer, with Micro-CT sizes values ranging from $0.29 \mathrm{~cm}$ to $5.58 \mathrm{~cm}$ (average $1.13 \mathrm{~cm}$ ) with the gross specimen sizes ranging from $0.1 \mathrm{~cm}$ to $3.03 \mathrm{~cm}$ (average $1.16 \mathrm{~cm})$. The average difference between the Micro-CT size the gross specimen size was $0.26 \mathrm{~cm}(0.00 \mathrm{~cm}$ to 1.23 $\mathrm{cm})$.

The size and shape of the spot seen on the Micro-CT is very similar to the size and shape of the cancer seen on the slide, as determined by analysis of the specimen after it had been cut into thick slices ("breadloafed") and placed in cassettes.

For 11 invasive ductal carcinomas, we carried out Micro-CT imaging not only of the intact specimen, but also of the specimen after it had been cut into thick slices ("breadloaffed') and placed into cassettes before they were immersed in formalin and then made into slides (FIGURE 5). The breadloaffed slices in cassettes were provided by the pathology lab in a sealed plastic container, imaged, and returned to the lab, without opening the container. The large size of the container slightly reduced the sharpness of the Micro-CT images. Nonetheless, with these breadloaffed specimens, we were able to make direct comparisons 
between the digital images of the cancer, as it appeared with the Micro-CT, and the corresponding optical images of the cancer, as it appeared through the microscope after processing. Assessments of the locations of the cancer on the slides were made by microscope examination of the slides and drawing the locations of the cancer on prints of the microscope images, made blind to the Micro-CT images, so as to avoid bias. Comparisons between the Micro-CT images and the slide images revealed a remarkable correspondence in the size (FIGURE 6, Person Correlation Coefficient 0.95, p<0.0001) and shape (FIGURE 7) of the areas judged to be cancer.

Comparison of the tumor size measurement made from the gross specimen by ruler and from the Micro-CT image digitally.

Which method provides the better measure of the actual size of the cancer: the manually executed ruler measurement or the Micro-CT measurement? By constructing cumulative distributions of these size measurements, visualized from the smallest specimen to the largest, it became apparent that sizes measured from gross specimens tended to be rounded in half centimeter increments $(0.5$ $\mathrm{cm}, 1.0 \mathrm{~cm}, 1.5 \mathrm{~cm}$, etc.), while sizes measured from Micro-CT images appeared more continuous (FIGURE 8 Bottom). On a log graph (FIGURE 8 Top) these cumulative distributions revealed Micro-CT size measurements to be more log-linear (reflected in $\boldsymbol{r}^{2}$ values), a feature previously demonstrated mathematically to be the size distribution more likely to be present in a population of patients. ${ }^{56}$ 


\section{$\underline{\text { Margin assessments by Micro-CT }}$}

\section{$\underline{\text { Reads for margin status }}$}

Micro-CT images of all 173 specimens were read to assess margin status, as defined by the image of cancer touching the edge of the specimen (TABLE 1). Reads were carried out with the Bruker Data-Viewer image visualization tool, scrolling through the entire specimen in the Z-dimension. Most reads took about half an hour, and all were carried out blind to the margin assessment of the pathologist to avoid bias

Among the 173 specimens, the pathologists judged $114(66 \%)$ to be margin positive. As noted above, most patients at our hospital are rendered margin free by shaved margin, thus making available an unusually large number of specimens for which the pathologists reported cancer at the edge. Among the 173 specimens in our dataset, Micro-CT identified an area where the image of the cancer touched the edge in 134 (77\%) of the cases.

\section{Micro-CT margin assessments of cases which the pathologist judged to be margin positive}

For those cases judged by the pathologist to be margin positive, the Micro-CT also showed an image of cancer that appeared to touch the edge of the specimen $93 \%$ of the time (TABLE 1). This was the case for $87 \%$ of DCIS cases, $92 \%$ of lobular carcinoma cases, $94 \%$ of non-multifocal invasive ductal carcinoma cases, $95 \%$ of invasive carcinoma cases (ductal and lobular together), $96 \%$ of invasive ductal carcinoma cases, and $100 \%$ of multifocal invasive ductal carcinoma cases.

\section{Micro-CT margin assessments of cases that the pathologist judged to be margin negative}

Remarkably, $47 \%$ of the cases judged by the pathologist to be margin negative yielded a Micro-CT image of cancer that appeared to be touching the edge of the specimen (TABLE 1). Such "Micro-CT-Only-Positive Cases" were found for 37\% of nonmultifocal invasive ductal carcinoma cases, $38 \%$ of invasive ductal carcinomas as a whole, $40 \%$ of invasive carcinomas (ductal and lobular together), $50 \%$ of multifocal invasive ductal carcinoma cases, $50 \%$ of lobular carcinoma cases, and $54 \%$ of DCIS cases.

\section{The cancer in "Micro-CT-Only-Positive Cases" only occupies a very small spot on the surface of the specimen.}

Do the "Micro-CT-Only-Positive Cases" truly identify surgical specimens for which cancer touches the edge? To gain insight into this question, we used 3D image analysis software to quantify how much of the edge of the specimen was occupied by the image of cancer (TABLE 2). Remarkably, for "Micro-CT-Only-Positive Cases" the cancer appeared to occupy only $0.45 \%$ of the surface area. On the other hand, for cases where both the pathologist and the Micro-CT image suggested cancer at the edge, the cancer appeared to occupy more than three times as much space, at $1.55 \%$ of the surface area ( $\mathrm{p}=0.027$ by $\mathrm{t}$-test).

In absolute terms, this analysis revealed that for "Micro-CT-Only-Positive Cases", the area where the cancer appeared to touch the edge constituted only $\sim 1 / 200^{\text {th }}$ of the surface area of the specimen. Note that the average size of the specimens we examined had a surface area of roughly $45 \mathrm{~cm}^{2}$ (TABLE 2), which is roughly the surface area of a 2.5 -centimeter cube. Since a 5-micron slice of such a cube is only about a $1 / 5000^{\text {th }}$ sample of the surface of the cube, this shows how plausible it could be that the area of positivity of "Micro-CT-Only-Positive Cases" could be absent from the several dozen slides that are generally available to the pathologist.

\section{Micro-CT imaging of breast cancer specimens.}

\section{DISCUSSION}

The findings reported here suggest that Micro-CT can provide full 3D images of partial mastectomy specimens; that the masses which appear to be cancer in these Micro-CT images really are cancer; that Micro-CT images can allow one to identify, in minutes rather than hours, and thus potentially while the patient is still on the operating table, those cases which the pathologist would later identify as margin positive, together with information on where the cancer touches the edge. The findings reported here also suggest that Micro-CT can rapidly identify as margin positive a number of cases that the pathologist is never able to identify, because the area where the cancer touches the edge of the specimen is exceedingly small.

Our experience in carrying out Micro-CT scans of surgical specimens taught us that collecting 3-D images is simple and quick. Imaging can be carried out without opening the plastic container into which the surgeon placed the specimen, and the imaging process doesn't impact subsequent pathological processing, workflow, or analysis of the case.

\section{Future possibilities}

The findings reported here raise the possibility that Micro-CT might provide the surgeon with a useful aid for achieving complete removal of cancer, while removing a smaller amount of normal tissue, in a larger number of patients. Micro-CT could also help minimize the problem itself, as it may well offer the surgeon a way to perfect surgical technique, so that incompletely removed specimens become less common. At the present time, breast surgeons essentially "work in the dark", as they are never able to see the full 3D dimensional structure of the cancers that they remove. One might suspect that with Micro-CT feedback on the full three-dimensional content of their specimens, surgeons may be able to perfect technique so as to achieve removal of the greatest possible amount of cancer with the smallest possible amount of non-cancerous tissue. 
Optical methods for observing the surface of cancer specimens are exceedingly impressive. ${ }^{17,18,20-22,26-30}$ However, the strength of optical technique in being able to image individual cells at high power is also its Achilles' heel. As we noted in the text, an average specimen has a surface of roughly $45 \mathrm{~cm}^{2}$, which is about 5 billion microns ${ }^{2}$. On the other hand, a 40x objective with a $20 \mathrm{~mm}$ eyepiece has a field of view of roughly a half a millimeter, or 250 microns $^{2}$. This means that there are approximately 20 million high power fields of view on the surface of an average partial mastectomy specimen, an impossibly large number of views to examine. However, there is no reason why one couldn't build a compound Micro-CT/optical device, which would collect both X-Ray data in the mass of the specimen, and optical data on the surface of the specimen, so as to allow the surgeon and pathologist to locate areas of concern with X-rays and go in for closer high-resolution surface images optically.

The studies we have reported here have focused on breast cancer. However, for many cancers, margin positivity, and finding ways to completely remove the tumor while minimizing loss of normal tissue, are challenges for which Micro-CT might be helpful.

Tumor size is an important determinant of outcome ${ }^{57}$, and thus its accurate assessment is valuable for optimal patient care. Micro-CT appears to readily offer direct volume assessment of the size of the tumor ${ }^{49,51}$ and may well be superior to the measurement of tumor size from the gross specimen that is made with a ruler. Of course, the majority of the specimens we examined were invasive cancers, whose sizes we have measured by Micro CT, but it has yet to be determined whether such size measurement for DCIS will have merit.

The Micro-CT devices we have used have resolution limits in the tens of microns range, not quite good enough to see breast cancer cells, but close. Breast cancer cells are 10 to 20 microns in size ${ }^{58}$, while platelets are about 2 microns, erythrocytes about 3 by 8 microns, lymphocytes about 10 microns, and hepatocytes 20 or more microns. ${ }^{59}$ We have employed the same Micro-CT equipment to image single lung and liver cells, although their special characteristics make them easier targets for detection. Microscopes used in pathology labs approach resolutions down to the diffraction limit, roughly half the wavelength of light, or about 0.2 microns. In comparison, X-rays have wavelengths of 0.01 microns or less, and, in fact, Micro-CT images generated with X-Ray beams created by impractically huge and expensive synchrotrons regularly resolve objects of 1 micron or less, ${ }^{60}$ reflecting the theoretical potential of this technology. Standalone Micro-CT machines are becoming gradually better, ${ }^{53}$ so it's not implausible that they may soon close the gap between their resolution limits and that of microscopes. Even now, the combination of Micro-CT and microscopy offers the possibility of providing complimentary information on the status of each surgical specimen, with Micro-CT having the capacity to display a fuzzy picture of the complete 3D content of a specimen, with microscopy providing the pathologist with higher resolution views of selected regions of the specimen at cellular-level resolution. 
Of course, it must be born in mind that Micro-CT does not yet have cellular level resolution. Thus, identifying what appears to be cancer in a Micro-CT image is intuitive rather than definitive. The fact that our independent, blinded, assessments of the size and shape of what appear to be cancer masses in Micro-CT images have proven to be remarkably similar in size and shape of the cancer masses seen on slides, is encouraging. However, we regard these findings to be considered as working observations, which await more rigorous assessment.

Here, we have been guided by the goal of providing a dispassionate report of what we have found in Micro-CT imaging of breast cancer specimens. These findings offer some tempting possibilities, but we feel strongly that they are just possibilities, worthy of testing. We feel especially strongly that these findings should not be interpreted to make any changes in the current methods in diagnosing or treating breast cancer.

At least two practical tasks stand in the way of realizing the full potential of Micro-CT to aid patients. Firstly, it is not enough simply to have the equipment: it is also essential to have the data/image management system that can efficiently capture the image stacks and make that information available to the surgeon and the pathologist. Secondly, however encouraging might be the findings reported here, it is not until Micro-CT's capacity to improve treatment, lower rates of re-excision, improve cosmesis, reduce the risk of local recurrence, and improve survival, are tested by trial that one could know for sure whether the promising observations noted here could be realized in practice. 


\section{FIGURE LEGENDS}

\section{FIGURE 1}

Micro-CT images of breast cancer specimens. Specimens imaged Bruker Data-Viewer image visualization tool, which presents trans-axial, coronal, and sagittal views in two dimensions, allowing for smooth scrolling and viewing the entire specimen at any angle.

A). A margin negative cancer. A search through the $\mathrm{z}$ dimension revealed normal issue on all sides of the cancer;

B). A margin positive case, for which the patient later returned for a mastectomy.

C) \& D): A margin positive case, for which the patient later returned for a re-excision operation. The mass was surrounded by normal tissue, but in one region, seen in C), the mass clearly touched the edge.

\section{FIGURE 2}

3-D Color visualization of a margin-negative specimen, rotated so as to show the specimen and its cancer from various angles. Images of Videos. Higher regions of X-ray absorption were rendered in red, while the surface of the specimen, which displayed a lower amount of X-ray absorption, was rendered in a translucent blue, and regions of intermediate X-ray absorption were rendered with low opacity, made the non-cancer areas transparent. The cancer thus appeared a red objected floating within the specimen.

\section{FIGURE 3}

Micro-CT image of a margin-positive specimen (TOP), and a margin-negative specimen (Bottom). Images of Videos. Images on the left rendered by software to reveal the surface of the specimens, while images on the right rendered by electronically slicing through the specimens, to reveal the interiors of the specimens, with the cancers made visible in red.

\section{FIGURE 4}

Comparison of the sizes of the spots seen on the Micro-CT and the sizes of the cancers seen at the time of dissection of the gross specimen.

\section{FIGURE 5}

Micro-CT images of the broad-loafed specimen in its cassettes.

\section{FIGURE 6}

Comparison of the sizes of the spots seen on the Micro-CT of the bread-loafed specimens and the sizes of the cancers seen on the microscope slide from which the bread-loafed specimens were made.

\section{FIGURE 7}

Spots seen on the micro-CT of the bread-loafed specimens and these cancers seen on the microscope slide from which the bread-loafed specimens were made.

\section{FIGURE 8}

Cumulative distributions of tumor size measurements made by Micro-CT (TOP) and on examinations of the gross specimen (BOTTOM) 
TABLE 1: Margin Status Assessments

\begin{tabular}{|c|c|c|c|c|c|c|c|}
\hline & \# & $\begin{array}{c}\text { Path+ } \\
\text { Micro-CT+ }\end{array}$ & $\begin{array}{c}\text { Path- } \\
\text { Micro-CT- }\end{array}$ & $\begin{array}{c}\text { Path+ } \\
\text { Micro-CT- }\end{array}$ & $\begin{array}{c}\text { Path- } \\
\text { Micro-CT+ }\end{array}$ & $\begin{array}{c}\text { \% of Pathologically } \\
\text { Judged } \\
\text { Margin Positive } \\
\text { Specimens Seen to } \\
\text { be Margin Positive } \\
\text { on Micro-CT }\end{array}$ & $\begin{array}{c}\% \text { of Pathologically } \\
\text { Judged } \\
\text { Margin Negative } \\
\text { Specimens Seen to } \\
\text { be Margin Positive } \\
\text { on Micro-CT }\end{array}$ \\
\hline & & \multicolumn{2}{|c|}{ Concordant } & \multicolumn{2}{|c|}{ Discordant } & & \\
\hline Study Set as a Whole & 173 & $106(61 \%)$ & $31(18 \%)$ & $8(5 \%)$ & $28(16 \%)$ & $93 \%$ & $47 \%$ \\
\hline Invasive Carcinoma (Ductal and Lobular). & 143 & $77(54 \%)$ & $37(26 \%)$ & $4(3 \%)$ & $25(17 \%)$ & $95 \%$ & $40 \%$ \\
\hline Invasive Ductal Carcinoma & 129 & $66(51 \%)$ & $37(29 \%)$ & $3(2 \%)$ & $23(18 \%)$ & $96 \%$ & $38 \%$ \\
\hline Non-Multifocal Invasive Ductal Carcinoma & 108 & $51(47 \%)$ & $34(31 \%)$ & $3(3 \%)$ & $20(19 \%)$ & $94 \%$ & $37 \%$ \\
\hline 1 and 2 Focus Invasive Ductal Carcinoma & 118 & $58(49 \%)$ & $37(31 \%)$ & $3(3 \%)$ & $20(17 \%)$ & $95 \%$ & $35 \%$ \\
\hline
\end{tabular}

\section{TABLE LEGEND:}

Two complete Micro-CT reads were carried out for assessment of the margin status of all the 173 partial mastectomies in the study set. These reads were carried out blind to the results of the pathology reports, so as to avoid biasing the assessment. Two co-authors (DD, PB) made these reads, and the results from the two blind read studies were remarkably similar; the precise number from the DD read will be used here for clarity. Most reads took about a half an hour. Reads for margin status were carried out with the Bruker Data-Viewer, with contrast adjusted so as to show the air surrounding the specimen as dark (black), reflecting air's low X-Ray density absorption, and lighter (white) areas corresponding to areas of high X-Ray density absorption, recapitulating the familiar image of a film X-ray, with the cancer typically appeared as a light a gray spot over a field of tissue that is darker grey. The readers scrolled through the entire specimen in the Z-dimension, imaging one computer generated section (20-70 microns) at a time. Using a sample X-Ray guide image (called SPR) each dataset was explored around key areas marked by the biopsy clips and the Kopans' loops that had been placed in the patient before surgery; these localization features were almost always found to coincide with the region of invasive and in situ carcinomas. The extent in each direction (x, y, z) of the suspected malignant features was established and the margins of the specimen were carefully viewed by orienting the dataset along the tumor/margin axis. Any suspected spot of positivity was investigated further to confirm that it was continuous with the tumor region and not a deceptively located benign density. Volumes not contiguous with the primary mass were not considered in the final assessment of margin judgment, and the case was accepted as Micro-CT margin negative. Each spot of margin positivity identified was assessed for the appearance of invasive ductal carcinoma, DCIS, or invasive lobular carcinoma in all three-dimensional planes. Results were recorded in an excel document, and only at the end of the study did the readers refer to the pathology reports. 
TABLE 2

The area of margin positivity on the surface of breast cancer surgical specimens.

\begin{tabular}{|c|c|c|c|c|c|c|c|}
\hline $\begin{array}{c}\text { Margin } \\
\text { Status as } \\
\text { Judged by } \\
\text { the } \\
\text { Pathologist }\end{array}$ & $\begin{array}{l}\text { Margin } \\
\text { Status as } \\
\text { Judged by } \\
\text { Examining } \\
\text { the Micro- } \\
\text { CT Image }\end{array}$ & $\begin{array}{l}\text { Average } \\
\text { Area of } \\
\text { Positivity } \\
\text { Measured } \\
\text { on the } \\
\text { Micro-CT } \\
\text { Image } \\
\left(\mathrm{cm}^{\wedge} 2\right)\end{array}$ & $\begin{array}{c}\text { Average } \\
\text { Specimen Area } \\
\text { Based on } \\
\text { Specimen Size } \\
\text { Measurements } \\
\text { (x y z) Made } \\
\text { of the Gross } \\
\text { Surgical } \\
\text { Specimen } \\
\left(\mathrm{cm}^{\wedge} 2\right)\end{array}$ & $\begin{array}{c}\text { Average } \\
\text { Specimen Area } \\
\text { Based on } \\
\text { Specimen Size } \\
\text { Measurements } \\
\text { Made by } \\
\text { Computer } \\
\text { Segmentation of } \\
\text { the Micro-CT } \\
\text { Image of the } \\
\text { Surgical } \\
\text { Specimen } \\
\left(\mathrm{cm}^{\wedge} 2\right)\end{array}$ & $\begin{array}{c}\text { Fraction of } \\
\text { Cancer } \\
\text { Touching the } \\
\text { Edge Based on } \\
\text { Specimen Size } \\
\text { Measurements } \\
\text { (x y z) Made } \\
\text { of the Gross } \\
\text { Surgical } \\
\text { Specimen }\end{array}$ & $\begin{array}{l}\text { Fraction of } \\
\text { Cancer } \\
\text { Touching the } \\
\text { Edge Based on } \\
\text { Specimen Size } \\
\text { Measurements } \\
\text { Made by } \\
\text { Computer } \\
\text { Segmentation of } \\
\text { the Micro-CT } \\
\text { Image of the } \\
\text { Surgical } \\
\text { Specimen }\end{array}$ & $\mathrm{p}$ \\
\hline NEGATIVE & POSITIVE & 0.512 & 49.406 & 97.640 & $0.983 \%$ & $0.454 \%$ & \\
\hline POSITIVE & POSITIVE & 0.971 & 41.869 & 96.490 & $3.21 \%$ & $1.55 \%$ & 0.0277 \\
\hline
\end{tabular}

TABLE LEGEND: To carry out these measurements, we measured the area where the cancer touched the edge of the specimen among pathologically-margin negative invasive ductal carcinoma cases that were either non-multifocal, or contained 2 foci (as specified by the pathologists), for which 58 were also found to be margin negative on Micro-CT ("Micro-CT-AND Path Positive Cases"), while 20 were found to be margin positive on Micro-CT ("Micro-CT-Only-Positive Cases".) (Analogous results were found when the dataset was limited to only the non-multifocal cases: data not shown.) The total surface area of the specimens was determined by using the Bruker CTAn software to segment out the specimen. The area of the spot of positivity was measured by using data viewer to load the dataset oriented about the spot of positivity. In each dimension of the spot (width; height) the dataset was oriented about the slice where this dimension was maximized. Once the area where maximum height and width was located, these values were measured using dataviewer's measuring tool and the area of the spot approximated by assuming it to be roughly elliptical.

\section{ACKNOWLEDGEMENTS:}

Many thanks for equipment provided by Bruker Skyscan and Nikon Metrology, and funding provided by Nikon Metrology. Micro-CT imaging was also provided at the MIT Center for Bits and Atoms, 20 Ames Street. Cambridge, MA 02139.

Many thanks to Drs. Barbara Smith and Michelle Gadd, and especially to Dr. Thomas Gudewicz for his gracious help wit the pathological aspects of this work.

\section{COMPLIANCE WITH ETHICAL STANDARDS}

\section{Disclosure of potential conflicts of interest}

\section{Funding}

This study was funded in part by an unnumbered contract from Nikon Metrology

\section{Conflict of Interest}

James Michaelson was the PI on the unnumbered contract from Nikon Metrology. James Michaelson has received no speaker honoraria from any company, nor does he own any stock, nor is he a member of any committee related to this work. Otherwise, none of the authors had any has no conflict of interest.

\section{Ethical approval:}

\section{Research involving human participants and/or animals}

This article does not contain any studies with animals performed by any of the authors.

All procedures performed in studies involving human participants were in accordance with the ethical standards of the institutional and/or national research committee and with the 1964 Helsinki declaration and its later amendments or comparable ethical standards.

\section{Informed consent}

Informed consent was obtained from all individual participants included in the study. 


\title{
REFERENCES
}

\begin{abstract}
${ }^{1}$ Isaacs AJ, Gemignani ML, Pusic A, Sedrakyan A. Association of Breast Conservation Surgery for Cancer With 90-Day Reoperation Rates in New York State. JAMA Surg. 2016 Jul 1;151(7):648-55

${ }^{2}$ Wilke LG, Czechura T, Wang C, Lapin B, Liederbach E, Winchester DP, Yao K. Repeat surgery after breast conservation for the treatment of stage 0 to II breast carcinoma: a report from the National Cancer Data Base, 2004-2010. JAMA Surg. 2014

Dec;149(12):1296-305
\end{abstract}

${ }^{3}$ Vrieling C, van Werkhoven E, Maingon P, Poortmans P, Weltens C, Fourquet A, Schinagl D, Oei B, Rodenhuis CC, Horiot JC, Struikmans H, Van Limbergen E, Kirova Y, Elkhuizen P, Bongartz R, Miralbell R, Morgan DA, Dubois JB, Remouchamps V, Mirimanoff RO, Hart G, Collette S, Collette L, Bartelink H; European Organisation for Research and Treatment of Cancer, Radiation Oncology and Breast Cancer Groups. Prognostic Factors for Local Control in Breast Cancer After Long-term Follow-up in the EORTC Boost vs No Boost Trial: A Randomized Clinical Trial. JAMA Oncol. 2017 Jan 1;3(1):42-48

${ }^{4}$ Houssami N, Macaskill P, Marinovich ML, Dixon JM, Irwig L, Brennan ME, Solin LJ. Meta-analysis of the impact of surgical margins on local recurrence in women with early-stage invasive breast cancer treated with breast-conserving therapy. Eur J Cancer. 2010 Dec;46(18):3219-32.

${ }^{5}$ Braunstein LZ, Taghian AG, Niemierko A, Salama L, Capuco A, Bellon JR, Wong JS, Punglia RS, MacDonald SM, Harris JR.Breast-cancer subtype, age, and lymph node status as predictors of local recurrence following breast-conserving therapy. Breast Cancer Res Treat. 2017 Jan;161(1):173-179.

${ }^{6}$ Mihalcik SA, Rawal B, Braunstein LZ, Capuco A, Wong JS, Punglia RS,, Bellon JR,, Harris JR, The Impact of Reexcision and Residual Disease on Local Recurrence Following Breast-Conserving Therapy. Ann Surg Oncol. 2017 Jul;24(7):1868-1873

${ }^{7}$ Vos EL, Gaal J, Verhoef C, Brouwer K, van Deurzen CHM, Koppert LB.Focally positive margins in breast conserving surgery: Predictors, residual disease, and local recurrence. Eur J Surg Oncol. 2017 Oct;43(10):1846-1854.

${ }^{8}$ Bodilsen A, Bjerre K, Offersen BV, Vahl P, Ejlertsen B, Overgaard J, Christiansen P. The Influence of Repeat Surgery and Residual Disease on Recurrence After Breast-Conserving Surgery: A Danish Breast Cancer Cooperative Group Study. Ann Surg Oncol. 2015 Dec;22 Suppl 3:S476-85

${ }^{9}$ Michaelson JS,Chen LL, Silverstein M, Cheongsiatmoy JA, Mihm MV, Jr., Sober AJ, Tanabe KK, Smith BL, Younger J. Why Cancer at The Primary Site and In The Nodes Contributes To The Risk Of Cancer Death CANCER Nov 1;115(21):5084-94 2009

${ }^{10}$ EBCTCG (Early Breast Cancer Trialists' Collaborative Group), McGale P, Taylor C, Correa C, Cutter D, Duane F, Ewertz M, Gray R, Mannu G, Peto R, Whelan T, Wang Y, Wang Z, Darby S. Effect of radiotherapy after mastectomy and axillary surgery on 10-year recurrence and 20-year breast cancer mortality: meta-analysis of individual patient data for 8135 women in 22 randomised trials. Lancet. 2014 Jun 21;383(9935):2127-35.

${ }^{11}$ Moran MS, Schnitt SJ, Giuliano AE, Harris JR, Khan SA, Horton J, Klimberg S, Chavez-MacGregor M, Freedman G, Houssami N, Johnson PL, Morrow M. Society of Surgical Oncology-American Society for Radiation Oncology consensus guideline on margins for breast-conserving surgery with whole-breast irradiation in stages I and II invasive breast cancer. Ann Surg Oncol. 2014

Mar;21(3):704-16.

${ }^{12}$ Morrow M, Van Zee KJ, Solin LJ, Houssami N, Chavez-MacGregor M, Harris JR, Horton J, Hwang S, Johnson PL, Marinovich ML, Schnitt SJ, Wapnir I, Moran MS. Society of Surgical Oncology-American Society for Radiation Oncology-American Society of Clinical Oncology Consensus Guideline on Margins for Breast-Conserving Surgery With Whole-Breast Irradiation in Ductal Carcinoma In Situ. J Clin Oncol. 2016 Nov 20;34(33):4040-4046

${ }^{13}$ St John ER, Al-Khudairi R, Ashrafian H, Athanasiou T, Takats Z, Hadjiminas DJ, Darzi A, Leff DR. Diagnostic Accuracy of Intraoperative Techniques for Margin Assessment in Breast Cancer Surgery: A Meta-analysis. Ann Surg. 2017 Feb;265(2):300-310

${ }^{14}$ Leff DR, St John ER, Takats Z Reducing the Margins of Error During Breast-Conserving Surgery: Disruptive Technologies or Traditional Disruptions? JAMA Surg. 2017 Jun 1;152(6):517-518

${ }^{15}$ St John ER, Balog J, McKenzie JS, Rossi M, Covington A, Muirhead L, Bodai Z, Rosini F, Speller AVM, Shousha S,

Ramakrishnan R, Darzi A, Takats Z, Leff DR Rapid evaporative ionisation mass spectrometry of electrosurgical vapours for the identification of breast pathology: towards an intelligent knife for breast cancer surgery. Breast Cancer Res. 2017 May 23;19(1):59

${ }^{16}$ Thill M, Baumann K, Barinoff J. Intraoperative assessment of margins in breast conservative surgery--still in use? J Surg Oncol. 2014 Jul;110(1):15-20. doi: 10.1002/jso.23634.

${ }^{17}$ Brachtel EF, Johnson NB, Huck AE, Rice-Stitt TL, Vangel MG, Smith BL, Tearney GJ, Kang D. Spectrally encoded confocal microscopy for diagnosing breast cancer in excision and margin specimens. Lab Invest. 2016 Apr;96(4):459-67.

${ }^{18}$ Coble J, Reid V. Achieving clear margins. Directed shaving using MarginProbe, as compared to a full cavity shave approach. Am J Surg. 2017 Apr;213(4):627-630

${ }^{19}$ Boughey JC, Hieken TJ, Jakub JW, Degnim AC, Grant CS, Farley DR, Thomsen KM, Osborn JB, Keeney GL, Habermann EB. Impact of analysis of frozen-section margin on reoperation rates in women undergoing lumpectomy for breast cancer: evaluation of the National Surgical Quality Improvement Program data. Surgery. 2014 Jul;156(1):190-7.

${ }^{20}$ Zysk AM, Chen K, Gabrielson E, Tafra L, May Gonzalez EA, Canner JK, Schneider EB, Cittadine AJ, Scott Carney P, Boppart SA, Tsuchiya K, Sawyer K, Jacobs LK. Intraoperative Assessment of Final Margins with a Handheld Optical Imaging Probe During Breast-Conserving Surgery May Reduce the Reoperation Rate: Results of a Multicenter Study. Ann Surg Oncol. 2015

Oct;22(10):3356-62. 
${ }^{21}$ de Boer LL, Hendriks BH, van Duijnhoven F, Peeters-Baas MT, Van de Vijver K, Loo CE, Jóźwiak K, Sterenborg HJ, Ruers TJ. Using DRS during breast conserving surgery: identifying robust optical parameters and influence of inter-patient variation. Biomed Opt Express. 2016 Nov 17;7(12):5188-5200.

${ }^{22}$ Wong TTW, Zhang R, Hai P, Zhang C, Pleitez MA, Aft RL, Novack DV, Wang LV. Fast label-free multilayered histology-like imaging of human breast cancer by photoacoustic microscopy. Sci Adv. 2017 May 17;3(5):e1602168.

${ }^{23}$ Diment J, Guterman A, Shapiro M, Peles Z, Maishar R, Gur A, Kolka E, Brem R. An intraoperative MRI system for margin assessment in breast conserving surgery: Initial results from a novel technique. J Surg Oncol. 2016 Jul;114(1):22-6

${ }^{24}$ Chagpar AB, Butler M, Killelea BK, Horowitz NR, Stavris K, Lannin DR.Papa M, Allweis T, Karni T, Sandbank J, Konichezky M, Does three-dimensional intraoperative specimen imaging reduce the need for re-excision in breast cancer patients? A prospective cohort study.Am J Surg. 2015 Nov;210(5):886-90

${ }^{25}$ Clarke GM, Holloway CM, Zubovits JT, Nofech-Mozes S, Liu K, Murray M, Wang D, Yaffe MJ. Whole-mount pathology of breast lumpectomy specimens improves detection of tumour margins and focality. Histopathology. 2016 Jul;69(1):35-44.

${ }^{26}$ Chang TP, Leff DR, Shousha S, Hadjiminas DJ, Ramakrishnan R, Hughes MR, Yang GZ, Darzi A. Imaging breast cancer morphology using probe-based confocal laser endomicroscopy: towards a real-time intraoperative imaging tool for cavity scanning. Breast Cancer Res Treat. 2015 Sep;153(2):299-310

${ }^{27}$ Tao YK, Shen D, Sheikine Y, Ahsen OO, Wang HH, Schmolze DB, Johnson NB, Brooker JS, Cable AE, Connolly JL, Fujimoto JG. Assessment of breast pathologies using nonlinear microscopy.Proc Natl Acad Sci U S A. 2014 Oct 28;111(43):15304-9.

${ }^{28}$ Brown JQ, Bydlon TM, Kennedy SA, Caldwell ML, Gallagher JE, Junker M, Wilke LG, Barry WT, Geradts J, Ramanujam N. Optical spectral surveillance of breast tissue landscapes for detection of residual disease in breast tumor margins. PLoS One. 2013 Jul 26;8(7):e69906

${ }^{29}$ Assayag O, Antoine M, Sigal-Zafrani B, Riben M, Harms F, Burcheri A, Grieve K, Dalimier E, Le Conte de Poly B, Boccara C. Large field, high resolution full-field optical coherence tomography: a pre-clinical study of human breast tissue and cancer assessment. Technol Cancer Res Treat. 2014 Oct;13(5):455-68.

${ }^{30}$ Nguyen FT, Zysk AM, Chaney EJ, Kotynek JG, Oliphant UJ, Bellafiore FJ, Rowland KM, Johnson PA, Boppart SA. Intraoperative evaluation of breast tumor margins with optical coherence tomography. Cancer Res. 2009 Nov 15;69(22):8790-6

${ }^{31}$ Amer HA, Schmitzberger F, Ingold-Heppner B, Kussmaul J, El Tohamy MF, Tantawy HI, Hamm B, Makowski M, Fallenberg EM. Digital breast tomosynthesis versus full-field digital mammography-Which modality provides more accurate prediction of margin status in specimen radiography?Eur J Radiol. 2017 Aug;93:258-264

${ }^{32}$ Miller CL, Coopey SB, Rafferty E, Gadd M, Smith BL, Specht MC.Comparison of intra-operative specimen mammography to standard specimen mammography for excision of non-palpable breast lesions: a randomized trial. Breast Cancer Res Treat. 2016 Feb;155(3):513-9

${ }^{33}$ Hisada T, Sawaki M, Ishiguro J, Adachi Y, Kotani H, Yoshimura A, Hattori M, Yatabe Y, Iwata H.Impact of intraoperative specimen mammography on margins in breast-conserving surgery.Mol Clin Oncol. 2016 Sep;5(3):269-272.

${ }^{34}$ van Bommel AC, Spronk PE, Vrancken Peeters MT, Jager A, Lobbes M, Maduro JH, Mureau MA, Schreuder K, Smorenburg CH, Verloop J, Westenend PJ, Wouters MW, Siesling S, Tjan-Heijnen VC, van Dalen T; NABON Breast Cancer Audit. Clinical auditing as an instrument for quality improvement in breast cancer care in the Netherlands: The national NABON Breast Cancer Audit. J Surg Oncol. 2017 Mar;115(3):243-249.

${ }^{35}$ Smith BL, Gadd MA, Lanahan CR, Rai U, Tang R, Rice-Stitt T, Merrill AL, Strasfeld DB, Ferrer JM, Brachtel EF, Specht MC.BuReal-time, intraoperative detection of residual breast cancer in lumpectomy cavity walls using a novel cathepsin-activated fluorescent imaging system. Breast Cancer Res Treat. 2018 Sep;171(2):413-420.

${ }^{36}$ Haloua MH, Volders JH, Krekel NM, Lopes Cardozo AM, de Roos WK, de Widt-Levert LM, van der Veen H, Rijna H, Bergers E, Jóźwiak K, Meijer S, van den Tol P. Intraoperative ultrasound guidance in breast-conserving surgery shows superiority in oncological outcome, long-term cosmetic and patient-reported outcomes: Final outcomes of a randomized controlled trial (COBALT). Ann Surg Oncol. 2016 Jan;23(1):30-7.

${ }^{37}$ Theunissen CI, Rust EA, Edens MA, Bandel C, Van't Ooster-van den Berg JG, Jager PL, Noorda EM, Francken AB. Radioactive seed localization is the preferred technique in nonpalpable breast cancer compared with wire-guided localization and radioguided occult lesion localization. Nucl Med Commun. 2017 May;38(5):396-401

${ }^{38}$ Langhans L, Tvedskov TF, Klausen TL, Jensen MB, Talman ML, Vejborg I, Benian C, Roslind A, Hermansen J, Oturai PS, Bentzon N, Kroman N. Radioactive Seed Localization or Wire-guided Localization of Nonpalpable Invasive and In Situ Breast Cancer: A Randomized, Multicenter, Open-label Trial. Ann Surg. 2017 Jul;266(1):29-35.

${ }^{39}$ Chagpar AB, Killelea BK, Tsangaris TN, Butler M, Stavris K, Li F, Yao X, Bossuyt V, Harigopal M, Lannin DR, Pusztai L, Horowitz NR. A Randomized, Controlled Trial of Cavity Shave Margins in Breast Cancer. N Engl J Med. 2015 Aug 6;373(6):503-10 ${ }^{40}$ Wang K, Ren Y, He J Cavity Shaving plus Lumpectomy versus Lumpectomy Alone for Patients with Breast Cancer Undergoing Breast-Conserving Surgery: A Systematic Review and Meta-Analysis. PLoS One. 2017; 12(1): e0168705

${ }^{41}$ Tang SS et al Current margin practice and effect on re-excision rates following the publication of the SSO-ASTRO consensus and ABS consensus guidelines: a national prospective study of 2858 women undergoing breast-conserving therapy in the UK and Ireland. Eur J Cancer. 2017 Oct;84:315-324.

${ }^{42}$ Morrow M, Abrahamse P, Hofer TP,, Ward KC, Hamilton AS, Kurian AW, Katz SJ,, Jagsi R. Trends in Reoperation After Initial Lumpectomy for Breast Cancer: Addressing Overtreatment in Surgical Management. JAMA Oncol. 2017 Oct 1;3(10):1352-1357 


\footnotetext{
${ }^{43}$ Butler-Henderson K, Lee AH, Price RI, Waring K. Intraoperative assessment of margins in breast conserving therapy: a systematic review. Breast. 2014 Apr;23(2):112-9

${ }^{44}$ Chan BK, Wiseberg-Firtell JA, Jois RH, Jensen K, Audisio RA. Localization techniques for guided surgical excision of nonpalpable breast lesions. Cochrane Database Syst Rev. 2015 Dec 31;(12)

${ }^{45}$ Gray RJ, Pockaj BA, Garvey E, Blair S. Intraoperative Margin Management in Breast-Conserving Surgery: A Systematic Review of the Literature. Ann Surg Oncol. 2018 Jan;25(1):18-27.

${ }^{46}$ O'Kelly Priddy CM, Forte VA, Lang JE. The importance of surgical margins in breast cancer. J Surg Oncol. 2016 Mar;113(3):256-
} 63.

${ }^{47}$ Tang R, Buckley JM, Fernandez L, Coopey S, Aftreth O, Michaelson J, Saksena M, Lei L, Specht M, Gadd M, Yagi Y, Rafferty E, Brachtel E, Smith BL. Micro-computed tomography (Micro-CT): a novel approach for intraoperative breast cancer specimen imaging. Breast Cancer Res Treat. 2013 Jun;139(2):311-6

${ }^{48}$ Tang R, Coopey SB, Buckley JM, Aftreth OP, Fernandez LJ, Brachtel EF, Michaelson JS, Gadd MA, Specht MC, Koerner FC, Smith BL A pilot study evaluating shaved cavity margins with micro-computed tomography: a novel method for predicting lumpectomy margin status intraoperatively. Breast J. 2013 Sep-Oct;19(5):485-9.

${ }^{49}$ Sarraj WM, Tang R, Najjar AJ, Griffin M, Zambeli-Ljepovic A, Senter-Zapata M, Ly A, Brachtel E, Aftreth O, Gilbertson J, Yagi Y, Gadd M, Hughes KS, Smith BL, Michaelson JS, Prediction of Primary Breast Cancer Size and T-Stage using Micro Computed Tomography (Micro-CT) in Lumpectomy Specimens. Journal of Pathology Informatics. 2015;6:60.

${ }^{50}$ Senter-Zapata M, Patel K, Bautista P, Griffin M, Michaelson JS, Yagi Y. The Role of Micro-CT in 3D Histology Imaging Pathobiology 2016;83:140-147

${ }^{51}$ Tang, R, Saksena M, Coopey SB, MD, Fernandez F, Buckley JM, Lan L, Aftreth O, Koerner F, Michaelson JS, Rafferty E, Brachtel E, MD, Smith BL Intraoperative Micro-computed Tomography: A Novel Method for Determination of Primary Tumor Dimensions in Breast Cancer Specimens The British Journal of Radiology 2016; 89: 2015

${ }^{52}$ Ligthart ST1, Coumans FA, Bidard FC, Simkens LH, Punt CJ, de Groot MR, Attard G, de Bono JS, Pierga JY, Terstappen LW. Circulating Tumor Cells Count and Morphological Features in Breast, Colorectal and Prostate Cancer. PLoS One. 2013 Jun 27;8(6):e67148.

${ }^{53}$ Müller M, de Sena Oliveira I, Allner S, Ferstl S, Bidola P, Mechlem K, Fehringer A, Hehn L, Dierolf M, Achterhold K, Gleich B, Hammel JU, Jahn H, Mayer G, Pfeiffer F,. Myoanatomy of the velvet worm leg revealed by laboratory-based nanofocus X-ray source tomography. Proc Natl Acad Sci U S A. 2017 Nov 21;114(47):12378-12383

${ }^{54}$ sse M, Müller M, Kimm MA, Ferstl S, Allner S, Achterhold K, Herzen J, Pfeiffer F,Three-dimensional virtual histology enabled through cytoplasm-specific X-ray stain for microscopic and nanoscopic computed tomography. Proc Natl Acad Sci U S A. 2018 Mar 6;115(10):2293-2298

${ }_{55}^{55}$ Fabian M. Troschel, Daniel DiCorpo, Molly Griffin, Julia Mario , Lida P. Hariri, Jo-Anne O. Shepard , Harald Ott , Cameron D. Wright, Ashok Muniappan, Michael Lanuti, James Michaelson, Florian J. Fintelmann. Perioperative 3-Dimensional Micro Computed Tomography of Human Surgical Lung Specimens: A Pilot Study American Journal of Respiratory and Critical Care Medicine 2017;195:A4903

${ }^{56}$ Michaelson JS Satija S, Moore R Weber G Garland G Kopans DB Estimates of the Breast Cancer Growth Rate and Sojourn Time from Screening Database Information Journal of Women's Imaging 5:3-10 2003

${ }^{57}$ Chen LL, Nolan, M, Silverstein M, Mihm MV, Jr., Sober AJ, Tanabe KK, Smith BL, Younger J., Michaelson JS, The Impact of Primary Tumor Size, Nodal Status, And Other Prognostic Factors On The Risk Of Cancer Death CANCER 115(21):5071-83 2009

${ }^{58}$ Milano et al. Regulators of Metastasis Modulate the Migratory Response to Cell Contact under Spatial Confinement. Biophysical Journal, 2016

${ }^{59} \mathrm{http}: / /$ www.nanomedicine.com/NMI/8.5.1.htm

${ }^{60}$ Larrue A, Rattner A, Peter ZA, Olivier C, Laroche N, Vico L, Peyrin F.Synchrotron radiation micro-CT at the micrometer scale for the analysis of the three-dimensional morphology of microcracks in human trabecular bone. PLoS One. 2011;6(7):e21297. 

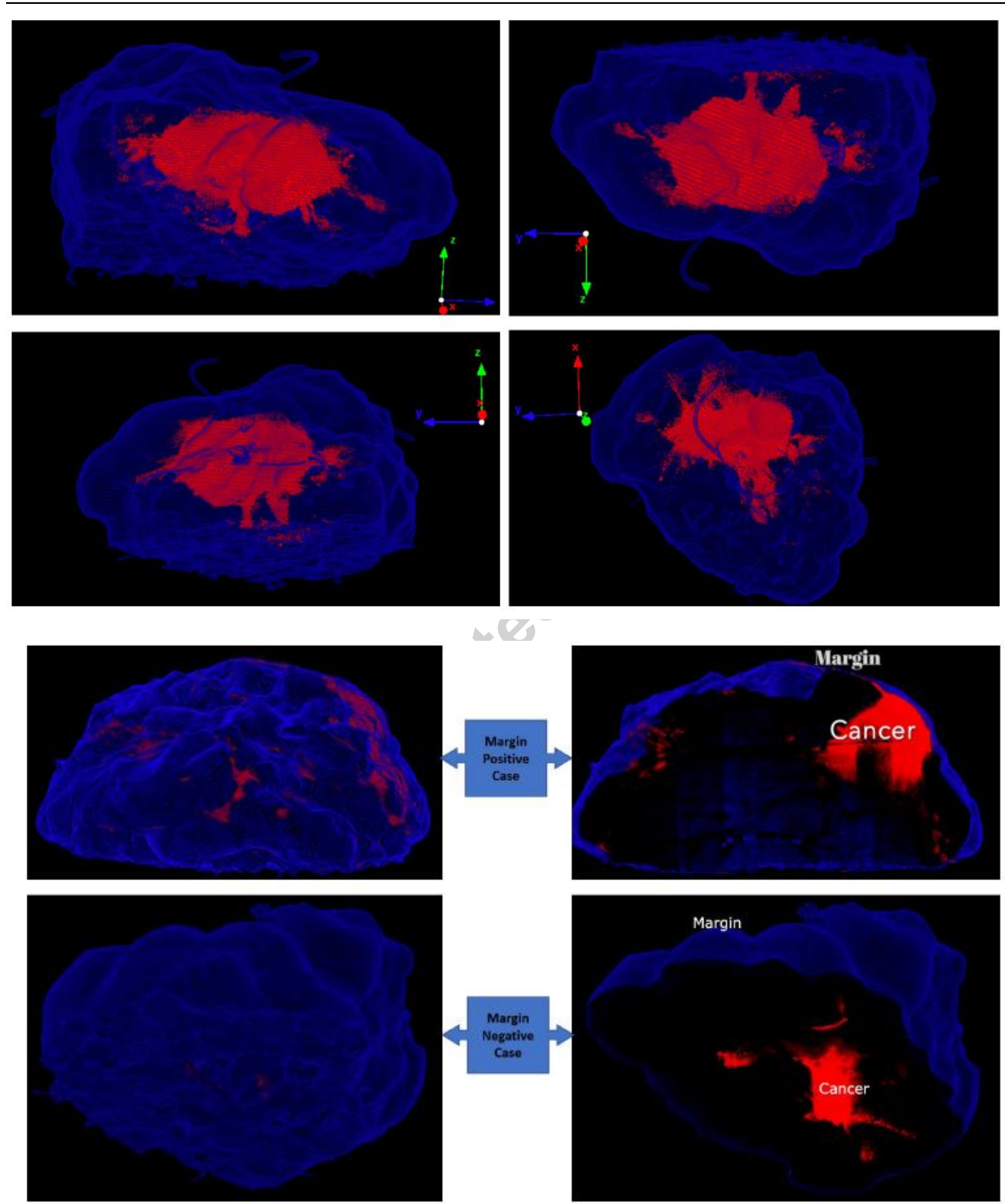


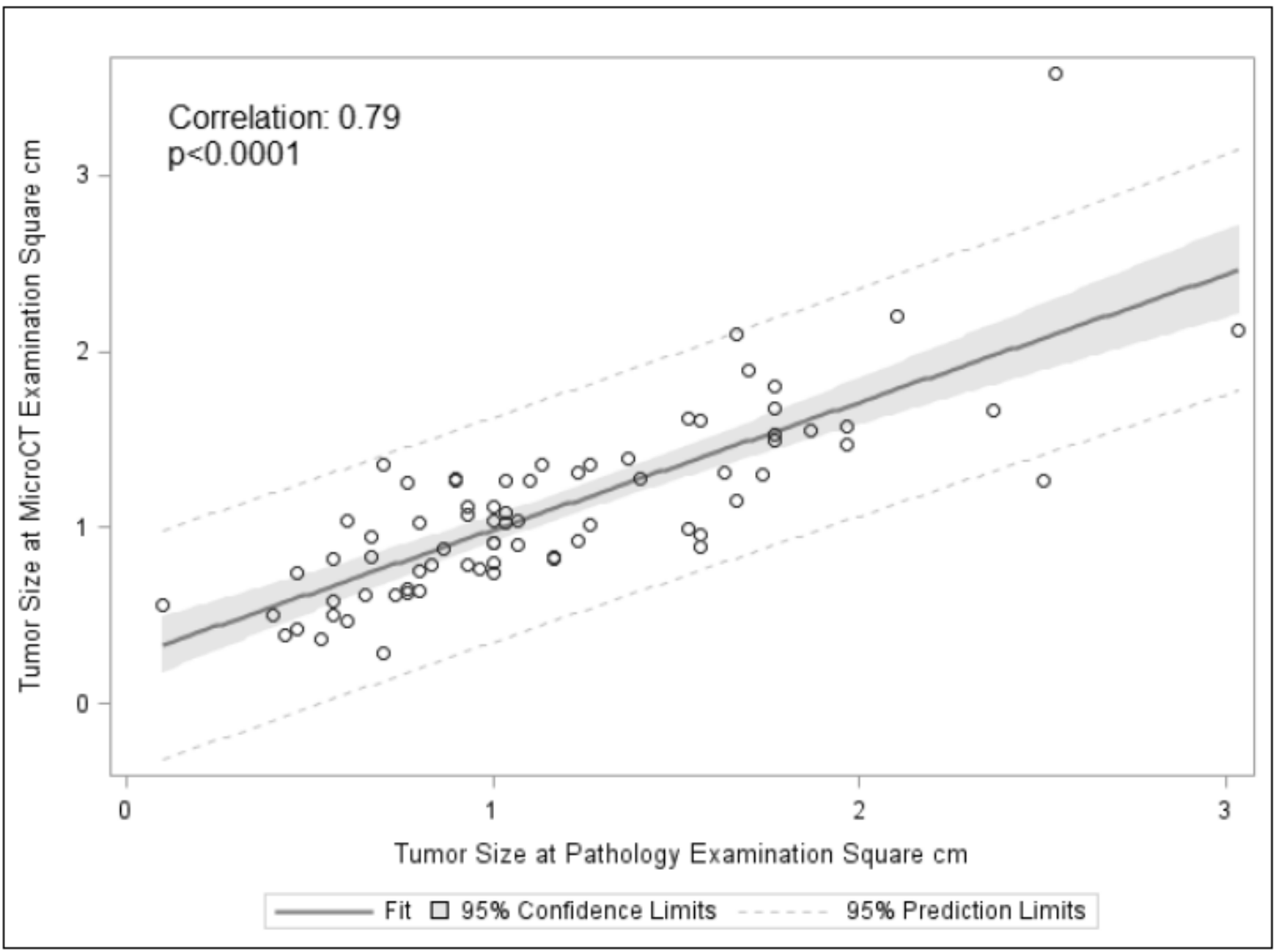

1 

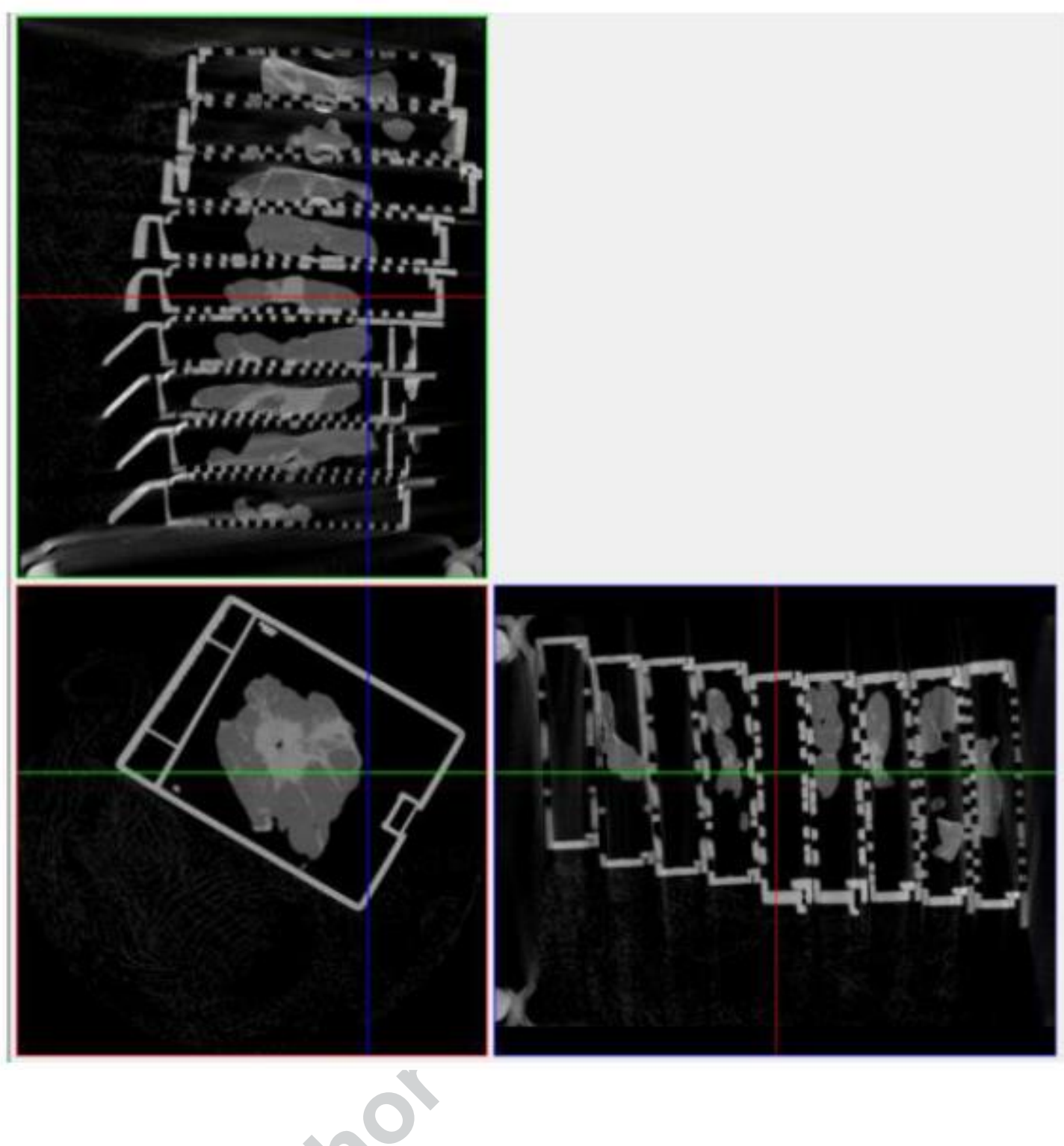


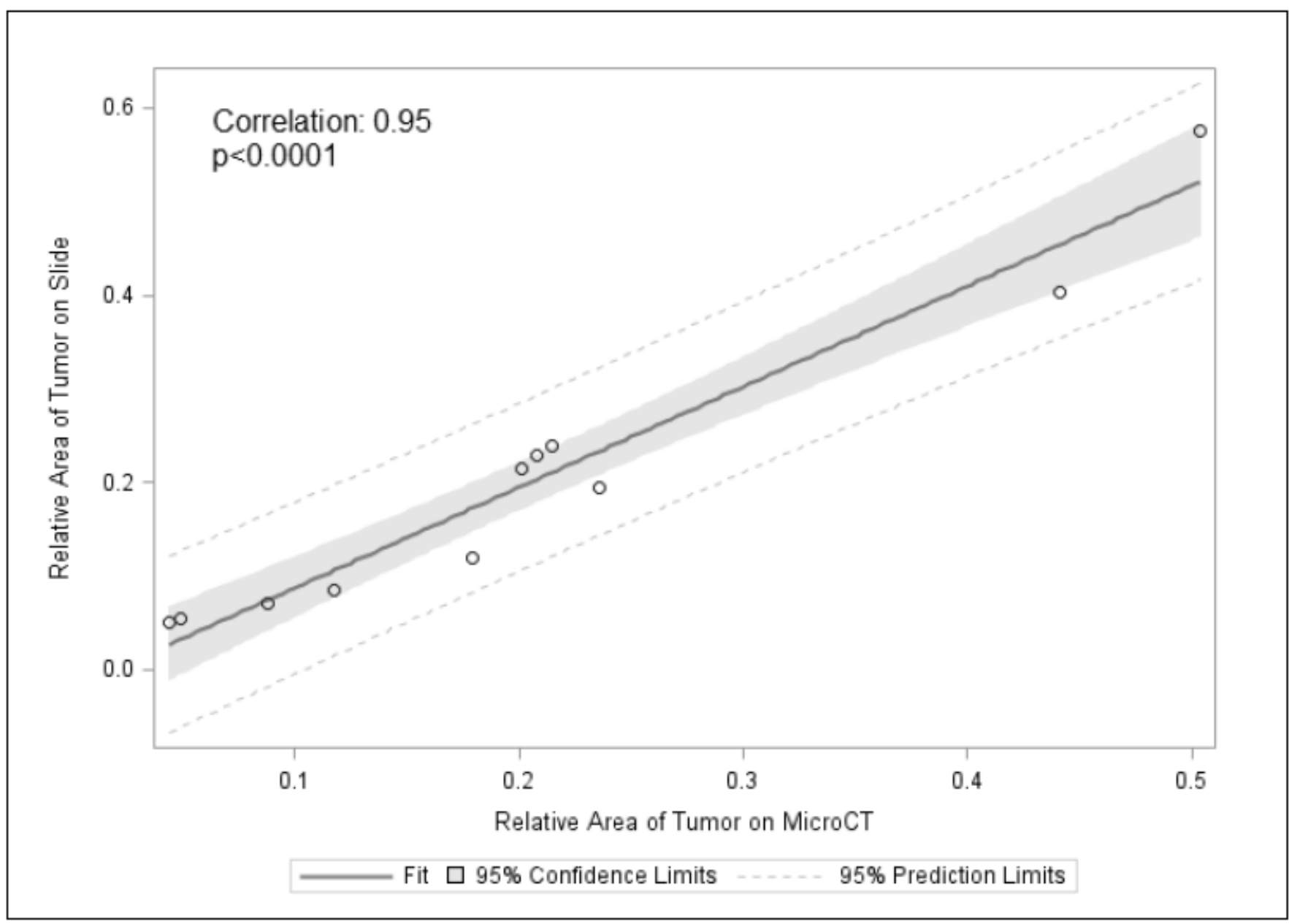

1 


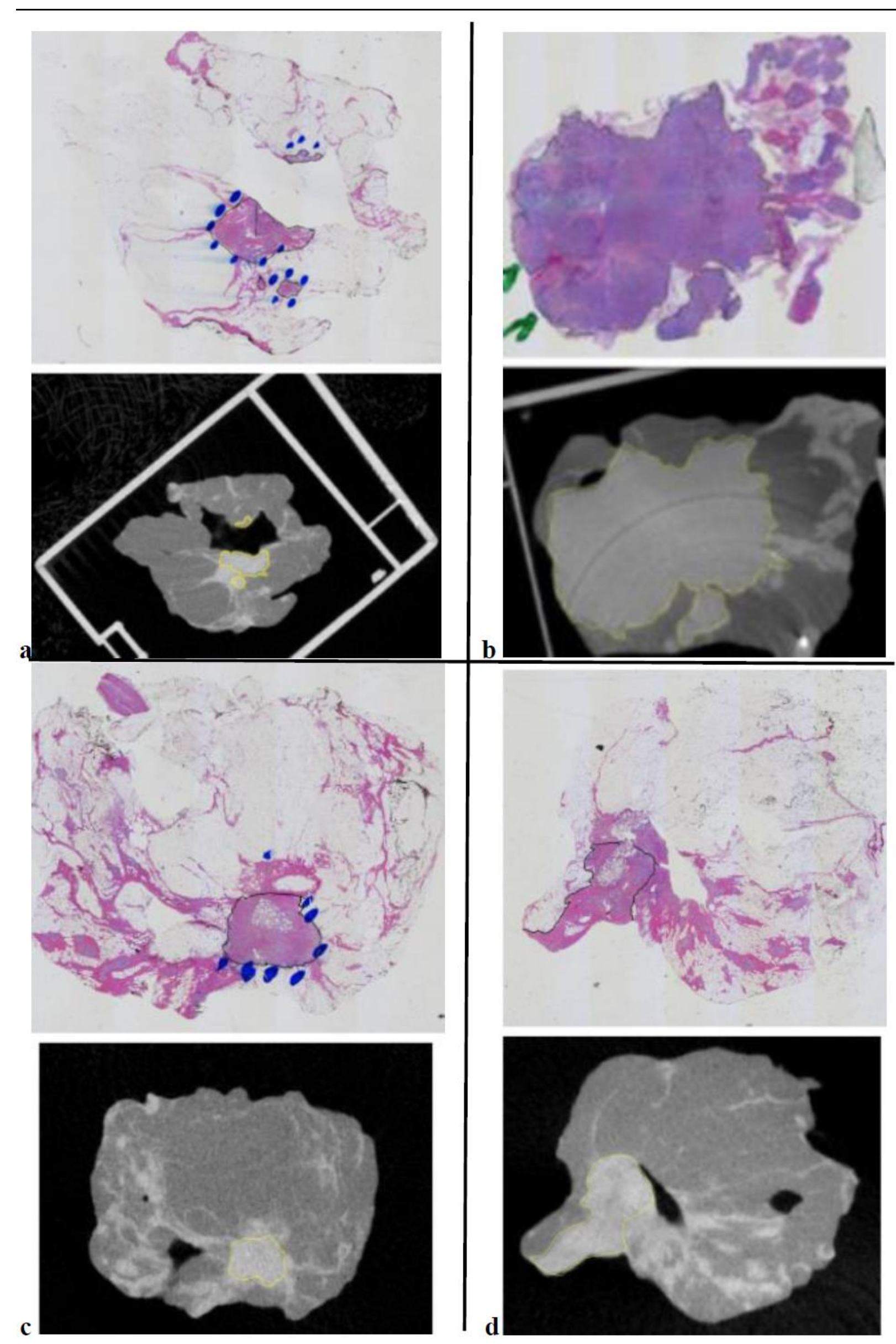

(C) 2020 Springer Science+Business Media, LLC, part of Springer Nature. 

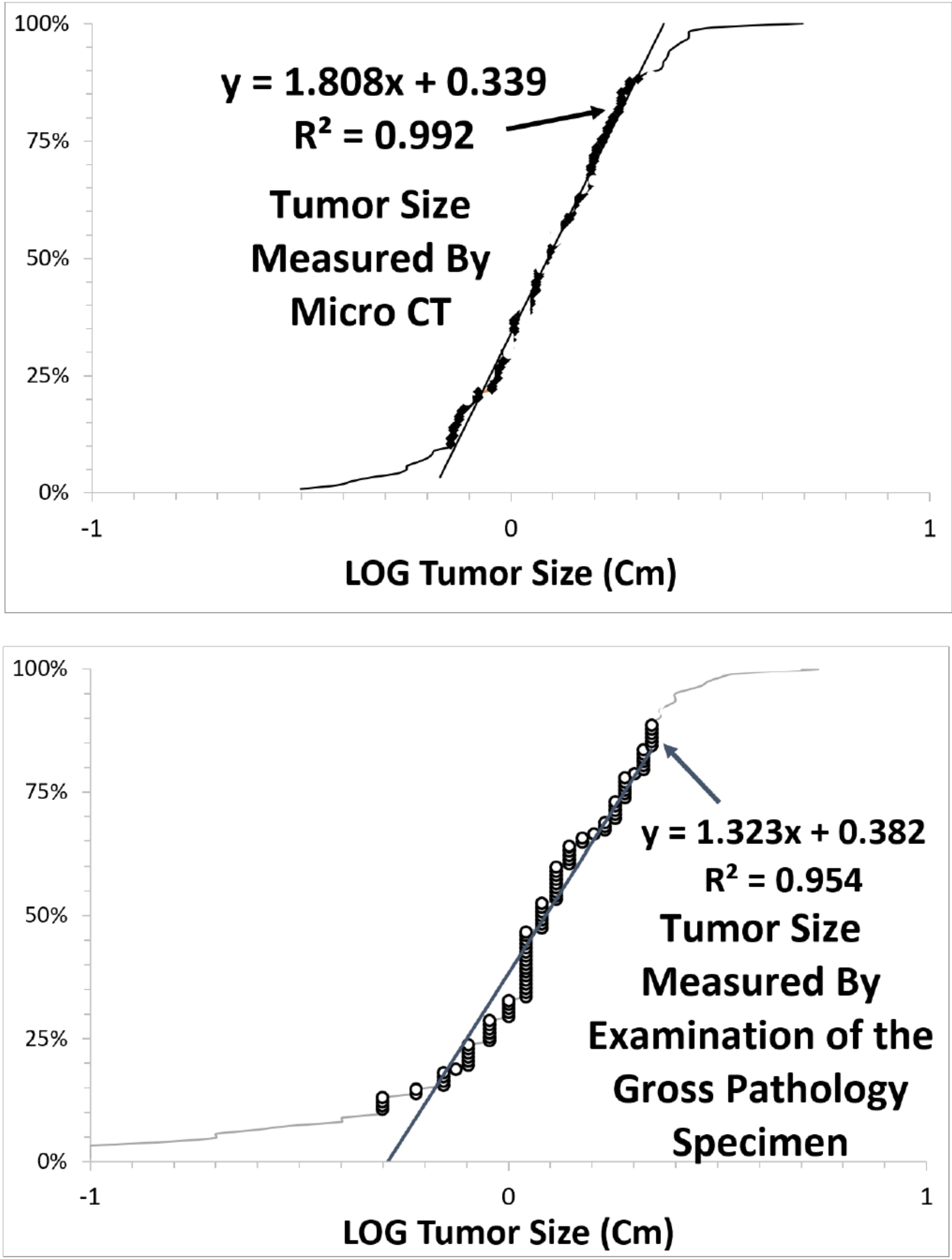